\title{
Major Statistical Series of the U.S. Department of Agriculture
}

\section{Costs of Production}

\author{
- Girrtri \\ PUBLIC ATFAIRS SERVICE \\ OCT \& 19987
}

UNIVERSITY OF CALHFORIA LOS ANGELES

\section{Maps and Gov Info Governmen awmohlet

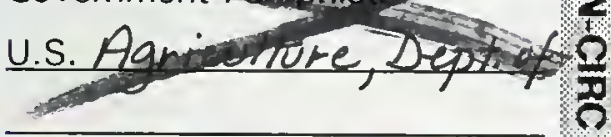

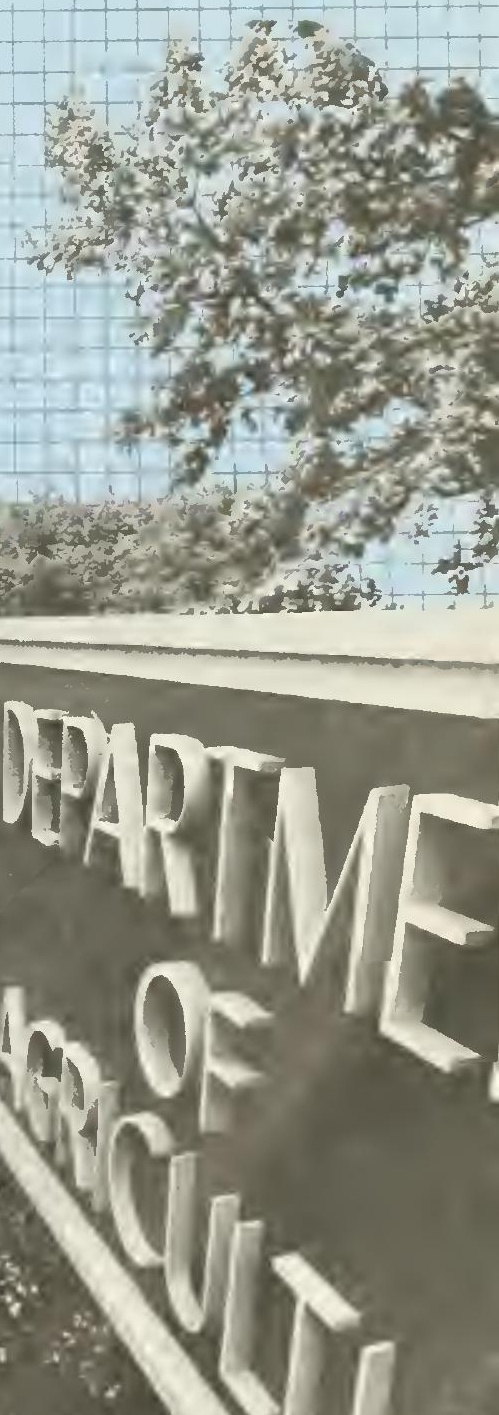


Major Statistical Series of the U.S. Department of Agriculture, Volume 12: Costs of Production. By Robert G. McElroy, Agriculture and Rural Economy Division, Economic Research Service, U.S. Department of Agriculture. Agriculture Handbook No. 671.

\begin{abstract}
The Economic Research Service of the U.S. Department of Agriculture estimates annual costs of production for major crops and livestock enterprises. Survey data, the main sources for these estimates, are compiled into a computerized budget generator to estimate enterprise budgets at regional and national levels. Each budget contains estimates of cash receipts, itemized cash expenses, economic (full ownership) costs, yields, prices, and net returns. This report describes the estimation procedures and the data sources for making the estimates.
\end{abstract}

Keywords

Costs of production, costs and returns, budget generator

\title{
Sales Information
}

Additional copies of this volume of the Major Statistical Series of the U.S. Department of Agriculture may be ordered from the Superintendent of Documents, U.S. Government Printing Office, Washington, DC 20402. Ask for the volume by name. Write to the above address for price information, or call the GPO order desk (202) 783-3238, and charge your purchase to your VISA, MasterCard, or (iP() deposit account.

Microfiche copies ( $\$ 6.50$ each) can be purchased from the National Technical Information Service, 5285 Port Royal Road, Springfield, VA 22161. Include the title and series number in your order. Enclose a check or moncy order payahle to NTIS: add $\$ 3.00$ for handling for each order. For faster service, call NTIS at (703) $487-4650$, and charge your purchase to your VISA, MasterCard, American Express, or NTIS Deposit Account. NTIS will ship rush orders within 24 hours for an extra $\$ 10.00$; call 800-336-4700. 


\section{Foreword}

This set of 12 volumes on the Major Statistical Series of the U.S. Department of Agriculture (Agriculture Handbook No. 671) is the second revision that supersedes the original volumes published during 1957-60. The first revision was completed in 1972.

Our goal for this handbook remains essentially unchanged. We hope to help government, university, private sector, and other users become better acquainted with the concepts and data underlying the Department's statistical series. We believe this handbook will benefit new users as well as those already familiar with the Department's statistics. If you find it valuable in improving your knowledge of what the various data series measure and how appropriate they may be for specific uses, we will have largely succeeded.

The challenge for our statistics is to reflect events in the agricultural sector and rural areas as they are, insofar as possible, and in this way contribute to public understanding. Because much has changed in the economics of rural areas and the food and fiber system since the last revision, we have adopted some new procedures. Thus, although the revised handbook describes several established series essentially as they were in the two earlier handbooks, it also notes changes in ongoing series, describes new series, and identifies some series that are no longer published.

Your interest in the Department of Agriculture's statistical series is important. We welcome comments on either these handbook volumes or the series they describe.

\section{Sharles \& Candiee}

CHARLES E. CAUDILL

Administrator, National Agricultural

Statistics Service

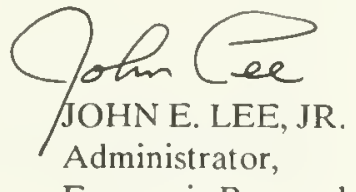

Economic Research Service 


\section{Volumes in Handbook}

Agriculture Handbook No. 671, Major Statistical Series of the U.S. Department of Agriculture, will consist of 12 volumes.

1. Agricultural Prices

2. Agricultural Production and Efficiency

3. Farm Income

4. Agricultural Marketing Costs and Charges

5. Consumption and Utilization of Agricultural Products

6. Land Values and Land Use

7. Crop and Livestock Estimates

8. Farmer Cooperatives

9. Market News

10. International Agricultural Statistics

11. The Balance Sheet and Farm Finance

12. Costs of Production

\section{Glossary}

The following organizational abbreviations appear in this publication:

ASAE American Society of Agricultural Engineers

ERS Economic Research Service, USDA

NASS National Agricultural Statistics Service, USDA

USDA U.S. Department of Agriculture 


\section{Acknowledgments}

The Economic Statistics Committee of the American Agricultural Economics Association, chaired by Leroy J. Hushak, Professor, Department of Agricultural Economics and Rural Sociology, The Ohio State University, arranged for helpful reviews by:

- Harry Mapp, Professor, Oklahoma State University, and

- James B. Johnson, Professor, Montana State University.

Edward Reinsel, Office of the Administrator, Economic Research Service, U.S. Department of Agriculture, coordinated the preparation of this and other volumes of the handbook. Judith Latham edited the manuscript. Carolyn Riley designed the cover and art work. Gwen Harris typed various drafts of the manuscript, and Patty Beavers prepared the camera copy. 


\section{Contents}

Page

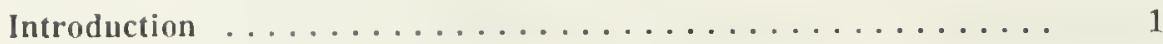

Survey Methods $\ldots \ldots \ldots \ldots \ldots \ldots \ldots \ldots \ldots \ldots \ldots \ldots$

Enterprise Budgets . .................... 4

Cash Receipts, Expenses, and Returns ............ 4

Economic Costs and Returns . . . . . . . . . . . . . 4

Use of Enterprise Budgets to Estimate Production Costs . . . . . . . 6

Preparation of Survey Results . . . . . . . . . . . . 6

Budget Assumptions and Data Sources . . . . . . . . . 8

Regional and National Aggregations $\ldots \ldots \ldots \ldots \ldots \ldots \ldots . \ldots 12$

Use of Cost-of-Production Data $\ldots \ldots \ldots \ldots \ldots \ldots \ldots \ldots \ldots \ldots$

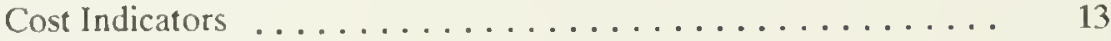

Return Indicators .................... 13

Annotated Bibliography ................... 15 


\title{
Major Statistical Series of the U.S. Department of Agriculture
}

\author{
Volume 12: Costs of Production
}

\author{
Robert G. McElroy
}

\section{Introduction}

The Agriculture and Consumer Protection Act of 1973 mandated the Secretary of Agriculture to conduct a costof-production (COP) study of wheat, feed grains, cotton, and dairy commodities and to establish current national weighted average costs of production. Furthermore, the Secretary was to cooperate with the land-grant universities, commodity organizations, general farm organizations, and individual farmers in making the COP study. The COP study was to be updated annually and to include all typical variable costs, a return on fixed assets equal to the existing interest rates charged by the Federal Land Bank, and a return for management comparable with the normal management fees charged by other comparable industries. These studies were to be based on the size unit that requires one person to farm on a full-time basis.

The 1973 act did not specify any uses for the cost estimates. However, the Food and Agriculture Act of 1977 had specific language requiring use of COP estimates (variable, machinery ownership, and general farm overhead costs) to adjust target prices for corn, wheat, cotton, and rice.

The 1981 legislation revised the 1973 wording to say: "...include all typical variable costs, including interest costs, a return on fixed costs, and a return for management." The legislation essentially deleted specifying the interest rate and the size requirement. It also deleted the requirement to use COP estimates in farm programs (except for peanuts). The U.S. Department of Agriculture's (USDA) Economic Research Service (ERS)

Robert G. McElroy is an agricultural economist with the Agriculture and Rural Economy Division, Economic Research Service, U.S. Department of Agriculture. simultaneously revised its estimation procedures for several costs, including interest, since actual cash interest payments were available from survey data. ERS also changed the format for presenting the COP budgets to reflect an estimated gross value of production, the out-ofpocket cash expenses and net cash returns, and economic (or full ownership) costs. The latter includes a return to the owned factors of production (land, labor, and capital) and a longrun residual return to management and risk for use in comparing the financial well-being of the enterprise with that of other enterprises.

The most recent legislation (the Food Security Act of 1985) did not address COP research directly, except for the peanut and sugar programs. Therefore, the wording of the 1981 act amending the 1973 act is still in effect.

Costs for commodities competing with the mandated enterprises have been added, mainly rice, peanuts, soybeans, flax, sunflowers, sugar, fed cattle, cow/calf, hogs. and sheep. Peanuts and sugar are essentially required now, as the 1985 act requires costs of production to establish the support level. Cost estimates for other commodities are planned.

This volume of Major Statistical Series of the U.S. Deparment of Agriculture discusses the procedures and data sources USDA uses to estimate production costs. It provides an information source for understanding USDA's COP program. Although the complexity of the USDA program makes it impossible to provide a detailed numerical background for every cost estimate, enough detail is given to describe data sources, concepts, and procedures used. 
ERS is responsible for estimating costs of production. It is also responsible for developing and using appropriate concepts to measure costs of production. One can use alternative procedures and concepts as well as alternative methods of gathering data. ERS depends on the cooperation of land-grant universities, commodity organizations, general farm organizations, and farmers to reach agreement on these concepts and procedures and insure an understanding of the COP program.

The current COP program goes beyond the scope of the former mandate in the following ways:
1. ERS provides costs for many more crop and livestock commodities than those specifically listed in the legislation.

2. ERS provides regional cost estimates for all commodities included in the program and provides costs by enterprise size for some commodities.

3. ERS estimates more detailed individual cost items.

4. ERS maintains numerous crop and livestock enterprise budgets by State and region. 


\section{Survey Methods}

For surveys conducted through spring 1984, USDA's National Agricultural Statistics Service (NASS, formerly the Statistical Reporting Service) drew a random sample from all producers who responded to acreage and production surveys. NASS sampled farms from the list of respondents with a probability proportional to size so that each unit of production (an acre or an animal) in the region had an equal chance of being included in the survey. Thus, these survcy data tend to represent acreages of surveyed crops on the larger commercial farms because such farms have more acres. For example, a 1,000-acre farm with 400 acres of a crop had twice the probability of being sampled as a 1,000-acre farm with 200 acres of the same crop. With the spring 1985 survey, NASS changed to a full probability, multiframe sample. This change meant choosing a sample from both a list frame (a list of producers in each State) and an area frame (a random set of land segments). By using a full probability survey, ERS can statistically test future estimates for accuracy.

The current survey is referred to as the Farm Costs and Returns Survey (FCRS). FCRS is an annual survey of farm costs, returns, and production practices. It is conducted by ERS and NASS each winter in 48 States. About half of the approximately 24,000 respondents are asked to complete a detailed expenditures and receipts questionnaire that asks for indepth information about the farming operation's costs and returns. Other respondents are asked for less detailed whole-farm costs and returns data and for COP information for one of several specific commodities. For example, Eastern and Western cow/calf operations and those involved in dairy, hog, and fall potato production were surveyed in 1986 for 1985 COP data. In 1985, data on sugar beet, pasture/forage, rice, and burley tobacco crops were gathered. Because of limited sample sizes and high enumeration costs, USDA cannot survey each COP commodity every year, so each crop or livestock enterprise is surveyed on a 4-year rotation. ERS updates these costs between survey years, using recent yields, prices, and price indexes provided by NASS.

The simplest procedure for determining the cost of producing a commodity might appear to be to ask farmers to report their costs for producing that commodity. This procedure is impractical, however, because few farmers keep records by individual enterprise. Even those who keep enterprise records generally use different accounting methods, making it difficult to obtain comparable costs.

Rather than solicit per-acre or per-unit costs dircctly from farmers, ERS uses more general methods. COP questionnaires from the FCRS obtain such information as field operations, size and type of equipment, fertilization rates, seeding rates, custom operations, and labor use. This information complements price and quantity data available from other surveys, including crop acreages, crop yields, prices received for agricultural commodities, prices paid for agricultural inputs, and fertilizer use on some commodities. Other data include land values and rental rates. COP surveys ask for the amount of hand labor for crops, as well as labor used for livestock production.

ERS estimated costs in Econonic Indicators of the Fann Sector: Costs of Production, $1985(5)^{\frac{1}{1}}$ by using data from the following surveys:

\begin{tabular}{|c|c|c|c|}
\hline Commodity & $\begin{array}{r}\text { Production } \\
\text { year } \underline{1}\end{array}$ & Commodity & $\begin{array}{c}\text { Production } \\
\text { year 1/ }\end{array}$ \\
\hline Corn & 1982,1983 & FIax & 1983 \\
\hline Sorghum & 1982,1983 & Cotton & 1982 \\
\hline Barley & 1982,1983 & Sugar beets & 1980,1984 \\
\hline Oats & 1983 & Sugarcane & 1980,1984 \\
\hline Wheat & 1982,1983 & Fed beef & $1980^{\circ}$ \\
\hline Rice & 1979 & Cow calf & 1980 \\
\hline Soybeans & 1982,1983 & Hogs & 1980 \\
\hline Sunf lowers & 1983 & Sheep & 1980 \\
\hline Peanuts & 1982 & Dairy & 1980 \\
\hline
\end{tabular}

1/The 1982 survey was conducted in the Southern States and the Pacific Northwest; the 1983 survey was conducted in the Northern States. For sugar, partial results from the 1984 survey have been incorporated in the 1984 and 1985 estimates.

1/Italicized numbers in parentheses refer 10 items in the annotated bibliography at the end of this volume. 


\section{Enterprise Budgets}

ERS prepares and presents COP estimates as enterprise budgets, which summarize all operator and landlord costs and returns associated with producing a commodity. ERS prepares enterprise budgets on a per-unit basis, such as one acre or one animal. Regional enterprise budgets represent weighted-average production technology and input use. A State enterprise budget covers each commodity in each major producing region. ERS weights these data according to each State's share of production and aggregates them to estimate the regional and national average costs of production.

Each enterprise budget contains cost and return measures separated into three major categories: cash receipts, cash expenses, and economic (full ownership) costs.

\section{Cash Receipts, Expenses, and Returns}

ERS includes an estimate of cash receipts (really the gross value of production) in the enterprise budgets so analysts can estimate the residual returns to management and owned resources used in the production process. These residual returns fluctuate because of changes in the harvest-month price (for crops), the average market price (for livestock), and expenses. ERS estimates the receipts by multiplying price times yield and by adding in any value of secondary products like straw (crops) or culled breeding stock (livestock). The receipt estimates provide information to assess the economic performance of a commodity in a particular year or over time by permitting analysts to calculate net returns.

Cash expenses are out-of-pocket variable and fixed costs incurred during the production process. ERS estimates the cash llow position of producers by subtracting cash expenses from the estimated gross value of production (cash receipts). ERS tabulates net returns (receipts less expenses) both before and after a charge for economic depreciation (the replacement of capital invested in buildings and machinery). In any given year, an operator may defer machinery and equipment purchases because of income or tax considerations. However, over the long run, operators must set aside funds to replace worn-out equipment if the operation is to continue on the same scalc. The residual returns reflect funds available from the specific crop or livestock enterprise for family living, debt retirement, or discretionary uses and should provide for economic depreciation of machinery and ecjuipment.

\section{Economic Costs and Returns}

When the cost of production is luased on cash receipts versus cash expenses, production costs vary widely because of differing degrees of debt among producers. This variation occurs because cash farm expenses include actual interest paid during the year on operating, intermediate, and long-term debt. The cash approach would be incorrect if comparisons were made among various commodities or between regions. But analysts can use total economic (full ownership) costs and returns for comparisons without regard for equity levels or tenure of producers.

Economic costs consist of cash expenses (less actua] interest charges), capital replacement, and imputed charges for the farmer's own factors of production. If cash expenses and replacement charges are subtracted from cash receipts, the residual return to owned inputs can then be allocated to cover the costs of land, machinery, labor, and capital invested in operating inputs during the production process with a residual return to management and risk. The cost allocation to land, machinery, and labor is based only on the imputed value of each item in the production process.

Individual operators have many methods of allocating residual returns to cover the costs of owned or fixed resources. Some operators assign a proportionately large return to cover landownership costs and then leave a small return to unpaid labor; others do the opposite. In the COP budgets, the procedure for allocating residual revenues to each asset is based on an annual rate of return that the producer could expect capital to earn in the current year.

The earnings value of an owner-supplied input during the production process is generally difficult, if not impossible, to estimate. For cxample, one cannot easily assess the additional revenue earned when a producer invests nore money in operating inputs than in incurring additional short-term debt. Therefore, ERS calculates the COP estimates by assuming that the rational producer expects money invested in variable production inputs to carn at least as much as if it were rented or placed in a savings account or similar financial instrument. ERS uses a relatively risk-frec rate of return, which is a measure of the opportunity cost of these funds, to estimate the imputcd annual return to invested operating capital. Among the numerous financial instruments available to producers. ERS uses the average 6-month U.S. Treasury bill rate to reflect a relatively risk-frec opportunity cost of funds.

ERS uscs a sinilar procedure to value the lime operators and others work on their farms. At a minimum, their unpaid labor is assumed to be worth the equivalent of the bired wage rate. In the crops budgets, total labor expense is divided into hired labor (a casl expense) and unpaid labor (a noncash expense) based on the average percentage of each reported in the FCRS. 
The annual expected return the average producer might receive from capital invested in machinery and other nonland production assets used in the production process is estimated from data published in Economic Indicators of the Farm Sector: National Financial Summary (6). A single real rate of return to production assets reflects the annual earnings of owner-supplied or owned assets for all commodities in all regions. Data are not available to estimate rates of return specific to various commodities and regions. ERS analysts calculate a rcturn to land for crops by using rental value as a proxy for land returns rather than by using the real rate of return to production assets; for livestock, they estimate land charges by using the real rate of return and the current land price.

Any additional return reflecting the operator's entrepreneurial skill appears in the residual return to management and risk. Returns to management and risk are the residual amount after all other resources are valued. The returns to management and risk can be evaluated only in light of the given allocation of residual returns; they are directly comparable only when analysts use the same procedure (same rates of return to each item) for those commodities. The longrun return to risk is expected to average near zero, although in any particular year it could be positive or negative, depending on weather and on supply and demand. The return to management should be positive in the long run, but the level is unknown and, thercfore, speculative. Thus, the residual returns to both management and risk are expected to average above zero over time.

Although an enterprise budget provides a cost estimate for producing a particular product, it does not provide information about farm income or returns to resources for the whole farm.

The remainder of this volume will emphasize procedures and data sources associated with preparing and updating enterprise budgets. 


\section{Use of Enterprise Budgets to Estimate Production Costs}

The major functions of the ERS program for developing COP estimates are:

- Collecting and filing data,

- Preparing enterprise budgets, and

- Calculating national and regional weighted-average costs .

The figure shows the dat a flow through the COP system, when one uses the budget generator, to produce COP estimates.

\section{Preparation of Survey Results}

When a crop is surveyed, the responses are first computerized by NASS. ERS receives the resulting data set, which contains the responses from all versions of the questionnaire (versions for detailed expenditures and for each COP commodity). Then analysts prepare tables to help sort the data by commodity. If the commodity were corn, for example, all corn versions would be sorted out for further analysis. ERS analysts then sort this corn subset by State, the lowest current level of disaggregation.

From this final State crop data set, analysts estimate most of the input items used 10 produce the crop. For example, they determine the average secding rates and fertilizer use. The machincs and equipment in use are determined and put in a regional machinery complenent. ERS anaiysts assemble all the survey data needed to describe corn production for surveyed States and put them in a format usable by a computer program that manipulates the survey data as wcll as data from other sources.

A central component of the COP project is a computerized budget generator. The budget generator is a means of systematically assembling individual items of cost data and developing an itemized enterprise budget for a particular commodity. The budget generator minimizes human error and facilitates use of standard procedures in developing budgets. It can store and use large quantities of data. As additional cost data become available or as input costs change, the new information is entered into the computer data files. An updated enterprise budget can then be produced based on the new or updated data.

Six basic files are associated with the budget generator: parameter sets, machinery complements, equipment sets, irrigation complements, budget files, and name lists.

\section{Parameter Sets}

Each State that has a COP enterprise has its own parameter set. Parameter data sets are items that do not change by commodity or enterprise within a Statc. For example, fuel and fertilizer prices are parameter-set data $(1,2,4,11,12,16)$. The per-gallon price of gasoline remains the same whether it is used for corn or hog production. Use of State parameter sets requires fewer data entries.

The most complicated part of the budget gencrator is the procedure for calculating costs of owning and operating machinery and cquipment. Each farm has a different set of machinery and equipment in tcrms of items owned and operated, age, and size. The budget generator uses machinery complements and equipment sets to calculate ownership and operating costs. The machinery complements are used primarily for crop budgets, and the equipment sets are used primarily for livestock.

\section{Machinery Complements}

The American Society of Agricultural Engineers (ASAE) has developed formulas to calculate machinery repair costs as well as a replacement allowance (economic depreciation), taxes, and insurance based on the cost of the machine and annual hours of use. Fucl consumption lor tractors is based on maxinum power takeolf (PTO) horsepower and a 55-percent load rate. For other fuclusing machines, consumption is computed at an hourly rate as defined in the machinery complement.

Other machinery costs are computed on a dollars-per-hour basis with costs defined by hours of use for each machine. Hours of use depend on machine size, speed, and field efficiency and on the number of times the operation is performed. Hours of machine time required are determined by enginecring "performanec" cquations. The theorctical time required for cach machine operation is adjusted by a factor that relates observed time to theoretical tinse. Per-acre time requirements for each machine are multiplied by the number of times the operation is performed to estimate hours of use.

ERS analysts rely on FCRS data to estimate machine use, size of machines, and number of times the operation is performed. They also determine the size combinations of pulled machines and tractors. Given such information, the budget generator calculates appropriate costs. 


\section{Cost-of-production (COP) and budget generator flow diagram}

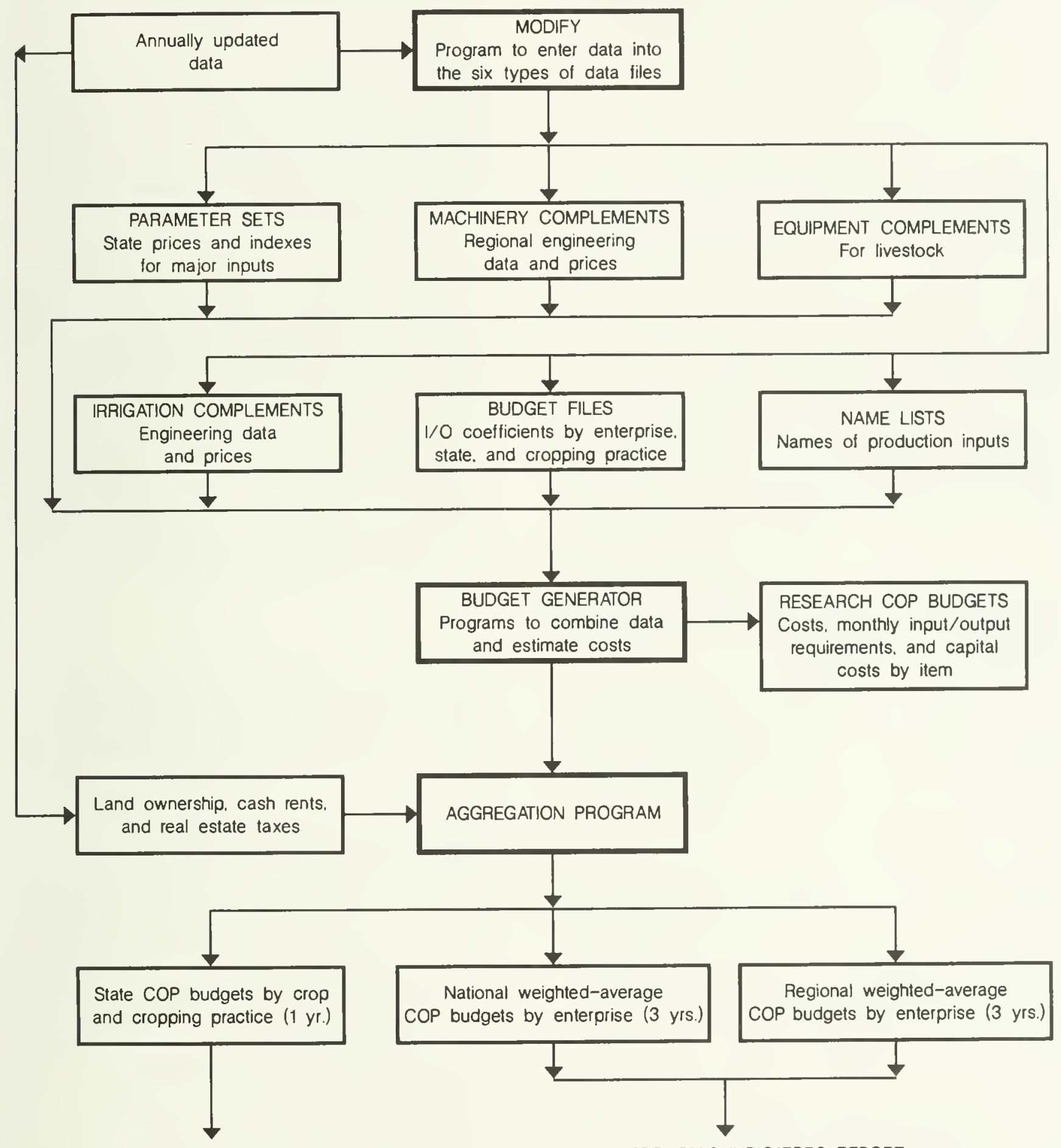

ANNUAL ERS STAFF REPORT

ANNUAL ECONOMIC INDICATORS REPORT 
The budget generator has machinery complements from which the analyst can select appropriate machinery for production of a specific commodity. A complement can include up to 100 machines and the additional data to compute ownership and operational costs. Each complement is specific for a region.

Machinery list prices and purchase prices are updated each year; machinery sizes, engineering coefficients, and annual hours of use are updated when new survey data become available. Estimates of average fuel prices and wage rates for each State are kept up to date in the parameter sets.

\section{Equipment Sets}

Equipment sets are generally needed along with machinery complements for livestock budgets. Crop budgets may require equipment sets in some cases, but the machinery complement is generally sufficient. ERS has developed 20 equipment sets from which analysts can select the appropriate items of equipment necessary to produce a specific commodity. Each set can include up to 100 items and the necessary data to compute their ownership and operational costs. Each set is specific for a region.

An equipment set used in a dairy enterprise, for example, includes buildings, water equipment and systems, milkhandling cquipment, hay- and manure-handling equipment, and brecding livestock.

Equipment cosis are computed for the entire livestock enterprise. ERS uses information obtaincd from COP surveys to determine sizes and types of equipment to use in the budget generator for calculating equipment costs.

\section{Irrigation Complements}

Many crop budgets have irrigation components and costs. Some 400 irrigation complements are available for describing the irrigation costs. A budget may call for one or more than one irrigation complement to describe the specific irrigation system being used. Each irrigation file has 66 line itcms describing the wells or water source, the pumps, the distribution systems, and the component costs.

\section{Budget Files}

Each cnterprise has its own budget filc. At any given lime, there are three years of data in the budget files. Secding ralcs, fertilizer application rales, and livestock fecding rates are examples of budget filc data. Prices of some inputs, such as seed, are also included. Annual updating is frequently done by a direct update of the budget file. For example, commodity yiclds and prices and secel prices are entered each year $(9,10,15)$. When new survey data are atvaliable, the entire data matrix must be entered. The physical input data are the same for each year in the case of enterprises that have not been surveyed during the past 2 years. Price data, however, change annually.

\section{Nanıe Lists}

These two data sets contain the names of the inputs and outputs for the budgets. One is for erops and the other is for livestock. Each name list contains 500 nanes of such items as "nitrogen," "chemicals," "protein supplements," and so on. They are used in the budget generator to identify cost items by name.

\section{Budget Assumptions and Data Sources}

Each State budget shows costs of producing a crop or livestock commodity under a specific type of production system (for example, wheat on fallow land, continuous cropped wheat, cow-calf production, or fed beef) in at designated geographic area. The budget estimates average costs and returns for all producers identified by type of operation in that area. Budgets represent "average" conditions, so costs for some individual farming operations are likely to differ significantly. The budgets have three major divisions: (1) cash reccipts, (2) enterprise cash expenses, and (3) economic (full ownership) cosis.

\section{Cash Receipts}

Enterprise cash receipts consist of estimated returns gencrated from producing the specific commodity. Cash receipts are a function of both yicld and price as reported by NASS. Yiclds are season averages replorted by NASS. Crop prices reflect harvest-month prices. Livestock prices reflect season-average market prices. Gains (losses) accruing from asset appreciation (depreciation) are not included. Weather is primarily responsible for yicld fluctuations, and supply and demand factors are primarily responsible for the ycarly price lluctuations. Costs per acre have until recently trended upward without sharp annual changes over recent decades. Thus, the volatility of cash receipts has becn the primary cause of thucuations in the amount of availahle cash and in returns to management and risk. Yield and price comparisoms are thus uscful in assessing whelier a given situation is temporary or long term in nature.

ERS includes the estimated gross value of production generated from the sale of hoth primary and secondary products. Sccondary products typically include itcms like coltonseed, the value of residues from crop production, or the sale of culled livestock. Total costs shown include those for the production of all primary and secondary products hecause such costs cammot be estimated separately. Therefore, ERS analysts estimate receipts and costs from all products. 
Conceptually, crop cash receipts may be based on either the season-average price received by farmers over the marketing period or the harvest-period price. For consistency, an analyst using season-average price would need to include storage and marketing costs in the budget. Prices used for crops in the COP accounts are average prices received by farmers in the harvest months. Dat a on marketing patterns and methods of storing and selling crops are not currently available. The COP budgets exclude any additional revenues the farmer may have earned by storing the crop for later sales as well as associated costs of storage.

Estimates of total returns omit direct Government pricesupport payments, except for wool. In the peanut, sugar, and milk programs, the Government supports the product price through direct market intervention. Estimated value of production, therefore, reflects the combined market price and masks Government payments. In contrast, most crop price-support programs are voluntary and contain special compliance provisions. When using cost and return information to judge whether support prices will encourage or maintain production at adequate levels, one should exclude both program payments and compliance costs.

\section{Cash Expenses}

Cash expenses consist of both variable expenditures (those incurred only if production takes place in a given year) and fixed expenditures. Fixed expenditures include taxes, insurance, overhead, and interest, for which the operator or landlord would be responsible whether or not a specific commodity is produced.

Variable cash expenses include such items as seed, fertilizer, lime and chemicals, custom operations, hired labor, fuel and lubrication, repairs, drying, ginning, purchased irrigation water, hired management fees, feed, and livestock hauling.

Data on seed quantities used per acre come from both Agricultural Statistics $(8)$ and COP surveys. Seed prices include both purchased hybrid varieties and homeproduced seed. For a crop like corn, which uses mostly hybrid seed, ERS takes purchased seed prices directly from State seed price estimates in Agricultural Prices (11). Estimated seed prices are used for home-produced seed; these prices follow the previous season's average prices plus an allowance for cleaning and treatment. Estimates of the share of seed purchased and produced at home come from either Field Crop Production: Disposition and Value (14) or COP survey data. Agricultural Prices (11) provides data on market prices for seed.
Fertilizer quantities for corn, cotton, soybeans, and wheat come from the Agricultural Resources Situation and Outlook: Inputs (4) report, which provides estimates of the quantity of fertilizer used by nutrient (nitrogen, phosphatc, and potash) in the major producing regions. For other crops, COP surveys provide data on fertilizer, lime, and gypsum use. Prices for all fertilizer materials come from Agricultural Prices (11).

COP surveys provide pesticide cost data, although individually identified pesticides are not listed because of the numerous chemical compounds and trade names. In nonsurvey years, pesticide costs are adjusted to follow the index of prices paid for farm chemicals listed in Agricultural Prices (11), a procedure that excludes annual changes in quantity. Variables affecting pesticide use and costs such as new chemicals, insect infestations, disease outbreaks, unusual weed problems, or rotation changes cannot be measured in nonsurvey years. However, because COP surveys give reliable estimates at regional and national levels, we assume that changes in localized pesticide use will not substantially affect aggregate figures

Custom operators and farmers alike apply pesticides. They often combine pesticide application with another farm machinery operation. Some dealers sell pesticides and then rent applicators to farmers. Many custom operators charge a flat rate, but do not provide a cost breakdown between application and materials applied. Cost estimates for custom services come from COP surveys supplemented by State information, when available. ERS updates these rates annually using a farm services and rent index publisher. by NASS and custom rate reports from individual States.

These cash expenses are relatively easy to estimate, hut the procedure for calculating the costs of owning and operating machinery and equipment is more complex because each farm has different types of machinery and equipment of varying ages and sizes. Most farms produce more than one commodity. Thus, any allocation of machinery costs among commodities must assess the relative use of machinery for each commodity.

COP estimates rely on the COP survey dat a for machine use, including size, type, and number of passes over the field. The COP surveys provide information that helps create a State or regional machinery complement that may contain up to 100 machines. Surveys also provide an indicator of the average number and size of machines necessary to produce a specific crop. ERS specifies the type of fuel used, age of machine when purchased, length of life, total hours of annual use, and list and purchase prices. 
Agricultural engineering formulas in the budget generator use such information in estimating fuel, repairs, machinery operation, labor, and ownership costs.

ERS computes machinery costs on a per-hour basis, and budget costs reflect hours of use of each machine, which in turn depend on the size of the machine and the number of times it passes over the acre. Engineering performance equations are used to determine the hours of machine time. The theoretically estimated machinery time must be adjusted for time lost in turning corners, refueling, and other interruptions. Per-acre time requirements for each machine are then multiplied by the number of times the machine moves over the the field to estimate total hours of use.

Fuel costs for tractors are related to power takeoff (PTO) horsepower, size, and fuel consumption at an assumed 55to 60 -percent load rate. For other machines, ERS gauges fuel consumption at the hourly rate specified for each machine. The cotal amount of fuel used to produce a commodity is the sum of all fuel used for each machine based on the estimated hours of use. Prices for fuels in each State, adjusted for refundable Federal and State excise taxes, come from Agricultural Prices (11).

ERS updates machine prices annually. The June annual summary of Agricultural Prices (11) shows average prices paid for some farm machinery. Prices of specialized machines and prices of optional equipment, which are not included in the NASS machinery price survey, are supplemented by current prices obtained from major farm machinery manufacturers. Hours of usc and ASAEprovided engineering equations determine tractor and machincry repairs.

Motor vehicle (truck and pickup) costs are included in the machinery costs for fuel, lubrication, and repairs. Farm operators in the COP surveys provide vehicle sizes, annual mileagc, and cstimated hours of use, and these cstimates are used to determine average hours of use per cropland acre. ERS estimates hourly vehicle costs and multiplies them by the estimated hours of usc per acre. Automobile expenses are included in general overhead expenses.

Estimates of drying expenses for a few crops mirror the percentage of the crop dricd and the initial moisture content. Estimates of the percentages of crops dried in the Corn Bclt, for example, comc from special reports published by States. Great Plains estimates requirc consulting with university and Extension Service staff and analyring results of special drying and storange studics. Annual updates include changes in fucl prices, yiclds, and initial moisturc content. Cotton ginning and wrapping costs are based on annual ERS studies of ginning practices and costs in major producing States.

COP survey data provide irrigation costs. In regions where wells are used for irrigation, procedures for estimating costs are similar to those used for machinery. Analysts obtain data on average well depth, pumping rates, and type of distribution system from the COP survey. Irrigation equipment, power units, and distribution systems, including the well, appear as part of a special irrigation complement. ERS also gathers power unit, distribution system, and well-drilling prices from State Extension Service budgets, State irrigation data, equipment dealers, and private companies. Machinery operation cost estimates include irrigation fuel, repair, and labor costs. Costs of purchased irrigation water appear as a separate item.

Estimated livestock expenditures include labor, feed (purchased and home-grown), hauling, breeding, veterinary fees and medicines, fuel and lubrication, machinery repairs, general farm overhead, and miscellaneous items.

Livestock operators mainly use farm-raised grains and forages as the primary source of feed in most livestockproducing areas. COP surveys provide data on use of farm-grown and purchased feed. ERS prices farm-grown forages at their variable costs of production, and it values purchased forages at their market price. NASS collects data on prices of baled hay to update purchased forage prices. ERS updates prices for each type of farm-grown feed using regionally weighted annual indexes. Purchased feed usually includes commercial fecd mixes, supplements, and other minor feed items, but may also include forages in many regions. Commodity-weighted indexes and NASS price data are used to price purchased grains $\mathrm{fcd}$. Grain grown for feed reflects market price rather than production cost. Updated commercial (mixed) feeds usc the prices from 14-percent protein feed.

COP surveys provide data on livestock hauling and regional livestock transportation costs, and ERS analysts update them between surveys using a weighted average of the farm and motor supplics index ( 70 percent) and the fucls and energy index ( 30 percent) as reported in Agricultural Prices (11). COP surveys also collect data on veterinary and medical expenses. The updating procedure reflects a weighted average of the nonagricultural hourly wage rate index ( 70 percent) and the agricultural chemicals index ( 30 percent).

Data on brecding fees and miscellancous expenses also come from the COP surveys. ERS updates these items annually, using the "all production itcms" index in Agricultural Prices (11). Fucl and electricity consumption 
rates per hour for operating special livestock equipment come from an unpublished study of energy use on dairy farms conducted in the midseventies by USDA and the Federal Energy Administration.

COP surveys measure labor data for livestock enterprises. Hired labor is a cash expense; hired labor used to produce farm-grown feed is included in the feed costs. The economic cost section carries total unpaid labor for the enterprise and for any farm-grown feed. Fixed cash expenses for crops and livestock consist of taxes, insurance, general overhead, interest, rent, and leasing costs. Taxes include personal property taxes on machinery and real estate taxes (7). Basing insurance and personal property tax estimates on current machinery and livestock prices can change this component of total cost. Therefore, tax and insurance costs for machinery are first computed based on current machinery prices and are then lagged 4 years, which assumes that major high-cost items in the machinery complements (such as tractors) are owned by the average commercial producer for about 8 years.

General farm overhead includes electricity for general farm use, telephone, office supplies, fees and dues, water drainage fees, liability insurance, fence repairs, and general business expenses. ERS collects costs for these items from the FCRS and allocates the costs among the commodities based on total farm receipts.

The annual FCRS also provides data on cash interest expenses. ERS calculates cash interest expenses for the farm business separately and reports them as a total for all nonland and real estate categories. Real estate interest consists of payments on loans secured by real estate. Interest on all other loans falls under the nonland category. ERS bases the enterprise interest expense on the FCRS percentage of total dollars of interest per dollar of total farm sales times the estimated COP budget receipts.

ERS estimates the costs of machinery, equipment, and breeding livestock based on current acquisition prices. Capital replacement represents a charge sufficient to maintain the machinery or livestock investments and production capacity through time.

The budgets include replacement costs associated with breeding stock. The value of purchased breeding animals is allowed to depreciate to salvage value. The number of years over which an animal's value depreciates varies by region and species. Animals used for replacement, but raised on the farm, are not depreciated because the cost of raising these replacements is included in the budget. Depreciating raised replacements would be double counting.

\section{Economic (Full Ownership) Costs}

Estimated economic (or full ownership) costs allow ERS analysts to compare commodity returns across varying levels of equity and tenure. Variable expenses, general farm overhead, and taxes and insurance in the "economic cost" section are the same as those in the "cash expenscs" section. The capital replacement allowance is also identical to that listed in the cash expenses section. After the above items are subtracted from estimated receipts, the remaining return to owned inputs must be allocated to operating capital, other nonland capital, unpaid labor, land, and management and risk because these costs cannot be determined during the production period through market transactions and must, therefore, be imputed.

ERS does not estimate the value of production assets, such as machinery, equipment, breeding livestock, and labor, at their acquisition costs. An average operator could expect these inputs to receive an annual return equal to their opportunity costs in alternate uses, exclusive of asset valuation changes because of inflation or deflation. The rate of return for any nonland asset used in the production process must be calculated from residual earnings from the current production process. Earnings from price appreciation (capital gains) or price depreciation are not included here or in the value of production or receipts section. ERS analysts calculate the rate of return for a given year by taking the average of the previous 10-year total return to production assets in the agricultural sector, subtracting the value of the operator's labor used each year, and dividing this figure by the value of production assets. All three series appear in Economic Indicators of the Fam Sector: National Financial Summary (6). The 10-year average calculated rates of return for $1978-85$ are:

\begin{tabular}{lccc} 
& Percent & & Percent \\
\cline { 4 - 4 } 1978 & 3.37 & 1982 & 3.02 \\
1979 & 3.34 & 1983 & 2.84 \\
1980 & 3.27 & 1984 & 2.26 \\
1981 & 3.09 & 1985 & 2.14
\end{tabular}

ERS charges the opportunity cost of operating capital on all variable inputs from the month of use to the harvest month. For example, seed corn is purchased and planted in April-May, and the crop is harvested 6 months later in October-November. The charge for annual capital needed for operating inputs uses the 6-month U.S. Treasury bill rate.

The expected rate of return generated by agricultural production assets determines the allocated return (cost) 
of capital invested in the remaining nonland factors of production. To calculate the annual earnings a producer can expect from machinery, equipment, and breeding livestock, one should multiply the total value of these assets by the rate of return to all production assets (for example, 2.14 percent in 1985).

ERS analysts calculate the return to land for livest ock enterprises in the same manner as the nonland factors, multiplying the average current land value by the 10-year rate of return. For dairy, land occupied by the barnyard and farm buildings receives a cost in the allocated returns section because the cost of land associated with feed production is already covered. For crops, however, ERS calculates a composite cash/share rental value by taking the per-acre cash rental rate and the per-acre share rental rate from survey data and by weighting each by its respective share of total acreage rented.

Because real estate taxes already appear in the taxes and insurance costs, ERS subtracts taxes from the rental value in the budget to prevent double-counting and to give a net rental value.

Machinery labor requirements for each budget relate directly to machinery time requirements. Labor is assumed to equal 110 percent of tractor use time (in the case of pulled implements) and 120 percent of selfpropelled implement use time. Because tractor use time is 110 percent of pulled implement time, labor associated with tractors and implements amounts to 121 percent of the implement use time. Total hours of labor equal the sum of all machine, irrigation, and livestock labor.
Additional labor may be added to budgets when applicable for irrigation or other hand operations as determined by COP survey data.

The wage rates for labor, based on data published in Farm Labor (13), are the sum of the State's annual average hourly rate for "all hired farm workers," plus the employer's share of Social Security taxes. One should subtract any expenses for hired labor from the total estimated labor cost to leave a return to unpaid labor provided by the operator, family, or others.

\section{Regional and National Aggregations}

Survey data are used to create State COP budgets for use by the budget generator. These budgets are the basis for regional and national weighted-average costs of production that ERS publishes in Economic Indicators of the Farn Sector: Costs of Production (5).

Another subroutine of the budget generator aggregates numerous State budgets into regional budgets. Additional data on land rents and real estate taxes are incorporated $(3,7)$. The weighting criterion is the percentage of total production each State has in relation to the total production for the defined region. States are grouped into production regions according to the cultural production practices most prevalent for the particular crop. The boundaries of production regions for onc crop, thereforc, may not be the same as those for another. Maps showing these regions for each crop appear in each annual COP report (4); States can be aggregated into other regions if desired. 


\section{Use of Cost-of-Production Data}

The table shows U.S. corn production costs from USDA's 1985 annual COP report. All receipts, costs, and returns have already been defined and explained. Although costs and returns in USDA's budgets are on a per-acre, per-cwt, or per-head basis, per-bushel or per-pound estimates can also be quite important for farm management or planning and for agricultural policy and program decisionmaking.

One can derive per-unit crop costs and returns by dividing each item's cost by the yields given with each budget or by trend yields determined elsewhere.

Each budget has four cost indicators and three return indicators. These indicators can be used for many purposes, so correct selection of the proper cost or return depends entirely on the user's objectives.

\section{Cost Indicators}

Cash expenses reflect the shortrun out-of-pocket variable and fixed costs incurred and, if converted to a per-bushel or per-unit cost, the minimum breakeven price needed on an average acre of cropland to raise and harvest a crop with a given yield. For example, when actual yields were used, corn cash expense per bushel ranged from $\$ 1.75$ to $\$ 2.54$ during $1983-85$, with an average per-bushel cash expense of $\$ 2.09$.

Cash expense with replacement includes the addition of capital replacement expenses and the dollars needed to replace the machinery and equipment used up during the production process, plus all cash expenses. To maintain the physical production plant over time, timely replacement of the capital stock is necessary.
Economic costs excluding land reflect all cash expenses (less cash interest), capital replacement, and allocated returns to labor, operating capital, and nonland capital. These costs indicate average longer run costs that must be somehow covered to keep an acre of land in production before payment of land rent, whether to the owneroperator or to the landholder.

Economic costs including land reflect total economic costs, including an estimated rent to the landowner. This measure, for which all longrun costs appear in the budget, indicates the breakeven longrun average price necessary to continue producing a crop. For example, the economic costs including land for producing corn ranged from $\$ 265.43$ to $\$ 294.59$ during $1983-85$, or a 3 -year average of $\$ 2.86$ per bushel.

\section{Return Indicators}

Net cash returns (receipts less cash expenses) are estimated by subtracting total cash expenses from total cash receipts.

Net cash returns after replacement (receipts less cash expenses and replacement) reflect cash available for paying the farmer's owned inputs after all cash costs are paid.

Residual returns to management and risk are the longrun economic indicators used to compare commodities and to assess relative returns among commodities.

The net returns, whether on a shortrun cash basis or a longrun economic basis, are the principal indicators of the firm's well being. 


\begin{tabular}{|c|c|c|c|}
\hline I tem & 1983 & 1984 & 1985 \\
\hline & \multicolumn{3}{|c|}{ Dollars per planted acre } \\
\hline \multicolumn{4}{|c|}{ Cash receipts (excluding direct Government payments): } \\
\hline Primary crop & 252.90 & 273.23 & 260.16 \\
\hline Total & 252.90 & 273.23 & 260.16 \\
\hline \multicolumn{4}{|l|}{ Cash expenses: } \\
\hline Seed & 16.65 & 18.03 & 18.47 \\
\hline Fertilizer & 48.03 & 50.93 & 50.03 \\
\hline Lime and gypsum & 1.59 & 1.58 & 1.53 \\
\hline Chemicals & 19.12 & 18.52 & 17.58 \\
\hline Custom operations & 6.69 & 6.86 & 7.05 \\
\hline Fuel, lube, and electricity & 15.96 & 14.14 & 13.49 \\
\hline Repairs & 10.34 & 11.16 & 11.25 \\
\hline Hired labor & 1.49 & 1.62 & 1.70 \\
\hline Purchased irrigation water & .35 & .36 & .35 \\
\hline Drying & 4.99 & 5.35 & 5.56 \\
\hline Miscell aneous & .23 & .23 & .23 \\
\hline Technical services & .83 & .81 & .85 \\
\hline Total, variable expenses & 126.27 & 129.59 & 128.10 \\
\hline General farm overhead & 15.22 & 15.37 & 15.29 \\
\hline Taxes and insurance & 13.45 & 16.77 & 17.16 \\
\hline Interest & 45.10 & 45.91 & 44.56 \\
\hline Total, fixed expenses & 73.77 & 78.05 & $\pi .01$ \\
\hline Total, cash expenses & 200.04 & 207.64 & 205.44 \\
\hline Receipts less cash expenses & 52.86 & 65.59 & 55.05 \\
\hline Capital replacement & 33.56 & 33.96 & 33.70 \\
\hline Receipts less cash expenses and replacement & 19.30 & 31.63 & 21.35 \\
\hline \multicolumn{4}{|l|}{ Economic (full ownership) costs: } \\
\hline Variable expenses & 126.27 & 129.59 & 128.10 \\
\hline General farm overhead & 15.22 & 15.37 & 15.29 \\
\hline Taxes and insurance & 13.45 & 16.77 & 17.16 \\
\hline Capital replacement & 33.56 & 33.96 & 33.70 \\
\hline \multicolumn{4}{|l|}{ Allocated returns to owned inputs: } \\
\hline Return to operating capital & 4.75 & 5.40 & 4.19 \\
\hline Return to other nonl and capital & 12.17 & 12.79 & 12.92 \\
\hline Net land rent & 47.95 & 67.61 & 57.46 \\
\hline Unpaid labor & 12.06 & 13.10 & 13.77 \\
\hline Total, economic costs & 265.43 & 294.59 & 282.59 \\
\hline Residual returns to management and risk & 12.53 & 21.36 & 22.43 \\
\hline Total, returns to owned inputs & 64.40 & 77.54 & 65.91 \\
\hline Harvest-period price (dollars/bushel) & 3.21 & 2.58 & 2.22 \\
\hline Yield (bushel/planted acre) & 78.76 & 105.79 & 116.96 \\
\hline
\end{tabular}

Source: (ㅁ). 


\section{Annotated Bibliography}

(1) Commerce Clearing House. State Tax Handbook. Washington, DC (not affiliated with the U.S. Department of Commerce). Contains a handbook for each State from which data on excise taxes on fuels are obtained. Published annually.

(2) Federal Reserve System. Federal Reserve Bulletin. Gives U.S. Treasury bill rates to use in allocating returns to operating capital. Published monthly.

(3) U.S. Department of Agriculture, Economic Research Service. Agricultural Resources: Agricultural Land Values and Markets Situation and Outlook Report. Reports on market developments, land values, cash rents, farmland transfers, market participants, financing of farmland. Published in July.

(4) Economic Research Service.

Agricultural Resources Situation and Outlook: Inputs. Provides information on U.S. outlook; U.S. fertilizer inventories, production levels, price and use; fertilizer use on crops, U.S. import export review; world fertilizer situation review and prospects; and supply and demand projections. Published each April and August.

(5) Economic Indicators of the Fann Sector: Costs of Production. Gives national and regional costs and returns for 18 major crops and 7 livestock enterprises. Published annually.

(6) . Economic Indicators of the Farm Sector: National Financial Summary. Details the farm sector's financial status on earnings, assets, and liabilities. Published annually.

(7) Famn Real Estate Taxes. Until recently, reported on the amount of property taxes levied on farm real estate, changes in these levies, and the relative burden of real estate taxes on farmers. The report covering these statistics will be retitled.

(8) U.S. Department of Agriculture, National Agricultural Statistics Service. Agricultural Statistics. Reports information on agricultural production,

supplies, consumption, facilities, costs, and returns. A U.S. report is released annually and supplemented by State reports as the information becomes available.

(9) and yields of major U.S. crops. Published each January as annual summary. yields of U $S$. small grains. Agricultural Prices. Reports prices received and paid by farmers including index numbers and parity price. Released monthly. Annual summary released in June of each year. information on mixed fertilizer consumption by class, direct application materials consumption by class, consumption of fertilizer mixtures and direct application materials by class, and average primary nutrient content of fluid fertilizers. The report is published monthly, and the November issue contains final consumption estimates for the year. on family and hired employment of farms. This report is published quarterly, and the February issue contains annual farm employment and annual average wages. and Value. Presents information on production, quantity used on farms where produced, quantity sold, price, and value. The report is published annually in April. output and number of cows by State. Published monthly.

(16) U.S. Department of Energy. Natural Gas Monthly. Gives natural gas prices by State by month. 

UNITED STATES DEPARTMENT OF AGRICULTURE ECONOMIC RESEARCH SERVICE

1301 NEW YORK AVENUE, NW.

WASHINGTON, D.C. 20005-4788

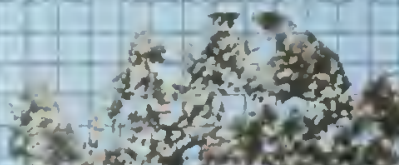

M.

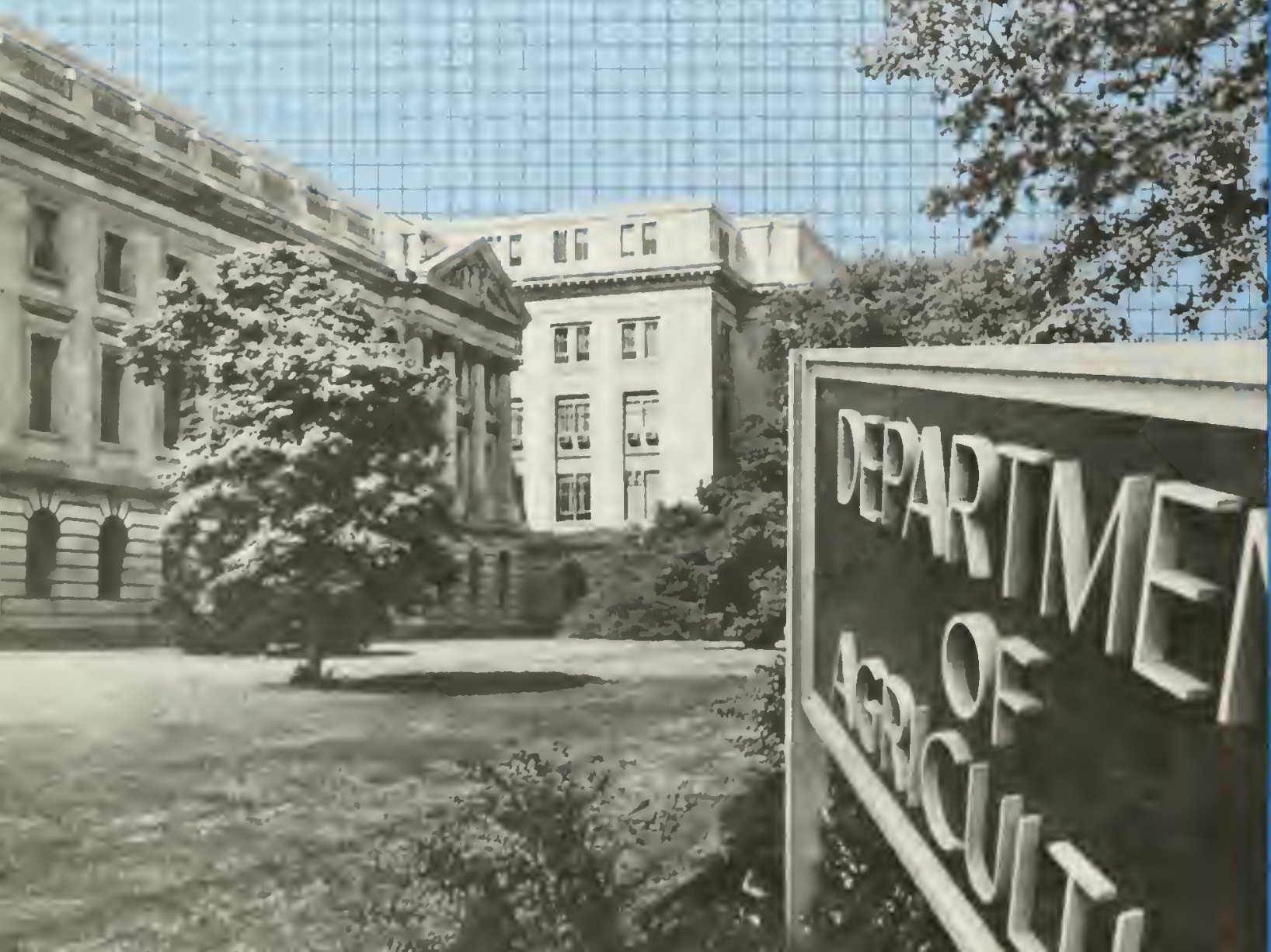

$+1+1+1=$

$10+2+2=$

IIt-2- +1 